\title{
Sarcopenia among the Elderly Population: A Systematic Review and Meta-Analysis of Randomized Controlled Trials
}

\author{
Di-Ya Tu ${ }^{1}$, Fa-Min Kao ${ }^{1}$, Shih-Tzer Tsai ${ }^{1,2}$ and Tao-Hsin Tung ${ }^{3, *}$ \\ 1 Department of Nutrition Therapy, Cheng-Hsin General Hospital, Taipei 112, Taiwan; \\ snoopy5386@hotmail.com (D.-Y.T.); felix19940728@gmail.com (F.-M.K.); tsaist60@gmail.com (S.-T.T.) \\ 2 Department of Internal Medicine, Cheng-Hsin General Hospital, Taipei 112, Taiwan \\ 3 Evidence-Based Medicine Center, Taizhou Hospital of Zhejiang Province Affiliated to Wenzhou Medical \\ University, Linhai 317000, China \\ * Correspondence: ch2876@gmail.com; Tel.: +86-576-8512-0120
}

check for updates

Citation: Tu, D.-Y.; Kao, F.-M.; Tsai, S.-T.; Tung, T.-H. Sarcopenia among the Elderly Population: A Systematic Review and Meta-Analysis of Randomized Controlled Trials. Healthcare 2021, 9, 650. https:// doi.org/10.3390/healthcare9060650

Academic Editor: Shinta Nishioka

Received: 23 April 2021

Accepted: 25 May 2021

Published: 31 May 2021

Publisher's Note: MDPI stays neutral with regard to jurisdictional claims in published maps and institutional affiliations.

Copyright: (C) 2021 by the authors. Licensee MDPI, Basel, Switzerland. This article is an open access article distributed under the terms and conditions of the Creative Commons Attribution (CC BY) license (https:/ / creativecommons.org/licenses/by/ $4.0 /)$.

\begin{abstract}
Purpose. This systematic review and meta-analysis was conducted to explore the effect of protein intake on the prevention and improvement of sarcopenia. Methods. We searched the Cochrane Library, PubMed, and EMBASE from inception to 20 May 2021. Two authors independently selected studies, assessed the quality of included studies, and extracted data. Any disagreement was resolved by discussion with a third author. Results. There were 12 studies that met the selection criteria among 53 eligible publications. The results of the study show that the protein intake has no significant effect on the physical performance-4 $\mathrm{m}$ gait speed, chair rise test, short physical performance battery, muscle mass-skeletal muscle mass index, and muscle strength—hand grip strength. Conclusion. Protein supplementation had no significant effect on $4 \mathrm{~m}$ gait speed and on improving skeletal muscle mass index, hand grip strength, chair rise test, and short physical performance battery. Additional randomized controlled trials are warranted to adequately assess the effect of protein supplementation on elderly sarcopenia.
\end{abstract}

Keywords: protein supplement; sarcopenia; elderly population; meta-analysis

\section{Introduction}

Sarcopenia is a major health issue among the older population due to the increased risk of adverse outcomes, including falls, frailty, disability, morbidity, and mortality [1]. Sarcopenia is a symptom of skeletal muscle mass and strength loss, and physical performance decline [2]. There is a significant change in body composition with age, such as a decline in muscle mass and gain in body fat. The muscle mass reduces with age, by about $1 / 3$ in those over 50 years old and by a further $15 \%$ in those between 70 and 80 years old [3]. On average, the estimated prevalence of sarcopenia in the elderly-those aged 60-70 years-is $5-13 \%$, and increases to $11-50 \%$ in those aged over 80 years [4].

From the nutrition viewpoint, protein intake in the diet is a key factor to know whether sarcopenia has happened or not. Protein is an important component of cells in the body. The human body uses amino acids to perform a number of metabolic functions, such as acting as enzymes, membrane carriers, and hormones [5]. Lack of protein in the body easily leads to frailty, as well as impaired immune function and wound healing [6]. The recommended dietary allowance of Taiwan for men and women aged 50-70 years is set at $55 \mathrm{~g}$ /day and $50 \mathrm{~g} /$ day, respectively, and for those aged above 71 years old, it is set at $60 \mathrm{~g} /$ day for men and $50 \mathrm{~g} /$ day for women [7]. More protein intake is recommended for the elderly due to age-related loss in total body protein, resulting in an increased risk of sarcopenia.

In recent years, many studies have indicated the effect of protein intake on sarcopenia through different types of protein such as soy protein, milk protein, whey protein, leucine, branched-chain amino acid, and $\beta$-hydroxy- $\beta$-methylbutyric acid. However, the effect of 
protein intake on sarcopenia among the elderly population is still not clear. This systematic review and meta-analysis was conducted to explore the effect of protein intake on the prevention and improvement of sarcopenia.

\section{Materials and Methods}

\subsection{Literature Search}

In this study, we conducted a systematic review and meta-analysis to assess the effect of protein intake on sarcopenia among the elderly population. We used the PICO framework to search the terms (P: Elderly OR Elder OR Older OR Aged) AND (I: Protein intake OR Leucine OR HMB OR $\beta$-hydroxy- $\beta$-methylbutyric acid OR $\beta$-hydroxy- $\beta$ methylbutyrate) AND (O: Muscle mass OR Muscle strength OR Hand grip strength OR Gait speed OR Chair stand test OR Short physical performance battery) in the following databases: PubMed, Embase, and the Cochrane Central Register of Controlled Trials from inception through 20 May 2021, for relevant publications without limitations in the English language.

This systematic review was carried out in accordance with the Preferred Reporting Items for Systematic Reviews and Meta-Analysis (PRISMA ${ }^{\circledR}$ ) statement guidelines. Figure 1 shows the process of the study selection. The search strategy is detailed in Table 1. The study protocol was registered on PROSPERO (No. 198995).

\subsection{Study Selection}

The included studies met the following inclusion criteria: the study design was a randomized controlled trial (RCT), participants were human, the experimental group received protein, and the control group received a placebo. Firstly, we discarded duplicate studies by screening titles and abstracts. Secondly, in accordance with the previously designed study inclusion criteria, eligible studies were extracted by reviewing full texts. The titles and abstracts of all studies identified by our search were independently assessed by two of the authors (Tu and Kao) for eligibility. These authors checked the full text of potentially eligible trials to determine whether they met the inclusion criteria. The third author (Tung) arbitrated when the two authors disagreed on the inclusion of a study.

\subsection{Data Extraction and Assessment of Potential Bias}

We performed the data extraction and risk-of-bias assessment process. For all articles included, the following characteristics were obtained: first author, publication year, study country, participants in the RCTs, characteristics of intervention and comparison groups, and main outcome measurements. We reviewed the titles and abstracts when searching the relevant studies after all references had been imported to EndNote ${ }^{\circledR}$ software. After a thorough appraisal of these selected publications, we indexed the full texts and subsequently assessed the risk of bias using the Cochrane Handbook for Systematic Reviews of Interventions [8]. The handbook includes seven domains of bias risk: (1) random sequence generation, (2) allocation concealment, (3) blinding of participants and personnel, (4) blinding of outcome assessment, (5) incomplete outcome data, (6) selective reporting, and (7) other sources of bias. We ( Tu and Kao) used the Cochrane Collaboration tool to assess the risk of bias in the included trials [9]. Any disagreement was resolved through discussion with the third author (Tung). 


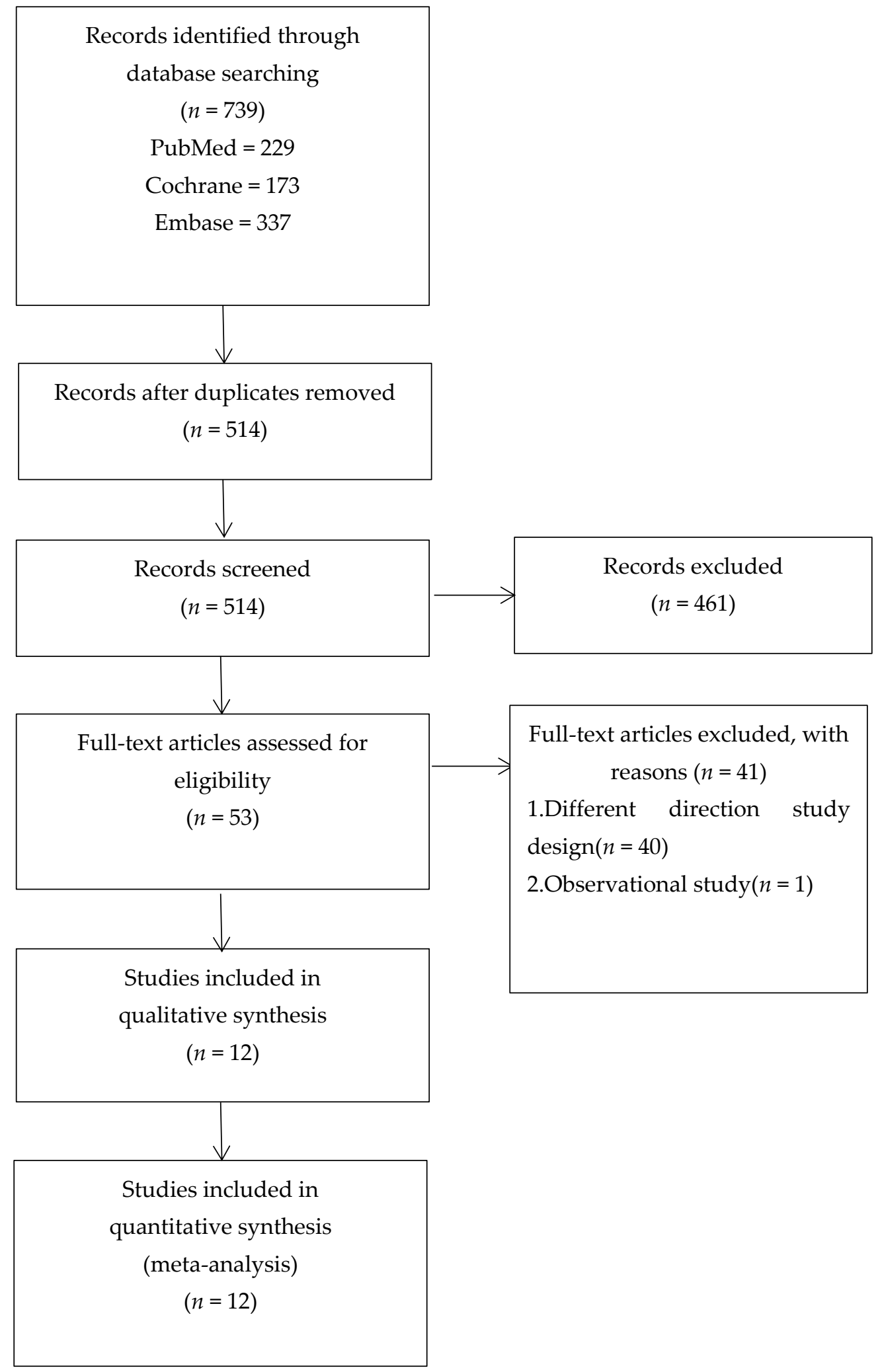

Figure 1. PRISMA flow diagram. 
Table 1. Search strategy in PubMed till 20 May 2021 (similar search run in Cochrane Library).

\begin{tabular}{|c|}
\hline 1. Elderly [MeSH Terms] OR [All Fields] \\
\hline 2. Elder [MeSH Terms] OR [All Fields] \\
\hline 3. Older [MeSH Terms] OR [All Fields] \\
\hline 4. Aged [MeSH Terms] OR [All Fields] \\
\hline 5. 1 OR 2 OR 3 OR 4 \\
\hline 6. Sarcopenia [MeSH Terms] OR [All Fields] \\
\hline 7. 5 AND 6 \\
\hline 8. Protein intake [MeSH Terms] OR [All Fields] \\
\hline 9. Leucine [MeSH Terms] OR [All Fields] \\
\hline 10. HMB [MeSH Terms] OR [All Fields] \\
\hline 11. $\beta$-hydroxy- $\beta$-methylbutyric acid [MeSH Terms] OR [All Fields] \\
\hline 12. $\beta$-hydroxy- $\beta$-methylbutyrate [MeSH Terms] OR [All Fields] \\
\hline 13. 8 OR 9 OR 10 OR 11 OR 12 \\
\hline 14. Muscle mass [MeSH Terms] OR [All Fields] \\
\hline 15. Muscle strength [MeSH Terms] OR [All Fields] \\
\hline 16. Hand grip strength [MeSH Terms] OR [All Fields] \\
\hline 17. Gait speed [MeSH Terms] OR [All Fields] \\
\hline 18. SARC-F questionnaire [MeSH Terms] OR [All Fields] \\
\hline 19. Chair stand test [MeSH Terms] OR [All Fields] \\
\hline 20. Short physical performance battery [MeSH Terms] OR [All Fields] \\
\hline 21. Time up and go test [MeSH Terms] OR [All Fields] \\
\hline 22. 6 min walking test [MeSH Terms] OR [All Fields] \\
\hline 23. 14 OR 15 OR 16 OR 17 OR 18 OR 19 OR 20 OR 21 OR 22 \\
\hline 24. Effect [MeSH Terms] OR [All Fields] \\
\hline 25. Effective [MeSH Terms] OR [All Fields] \\
\hline 26. Effectiveness [MeSH Terms] OR [All Fields] \\
\hline 27. Efficacy [MeSH Terms] OR [All Fields] \\
\hline 28. Improvement [MeSH Terms] OR [All Fields] \\
\hline 29. 24 OR 25 OR 26 OR 27 OR 28 \\
\hline 30. 23 AND 29 \\
\hline 31. 7 AND 13 AND 30 \\
\hline
\end{tabular}

\subsection{Statistical Analysis}

A conservative random-effects meta-analysis model was used throughout because of heterogeneity in study populations, interventions, and study designs. We used Review Manager version 5.4.1 to calculate the overall effect of protein intake on sarcopenia [10] for the elderly population. Heterogeneity in meta-analysis refers to variation in study outcomes between studies. In this study, we used the $I^{2}$ and inconsistency statistics. The statistics describe the percentage of variation across studies that is caused by heterogeneity rather than chance [11]; values of $<25 \%$, between $25 \%$ and $75 \%$, and $>75 \%$ were considered low, moderate, and high heterogeneity, respectively. A 95\% confidence interval (CI) was constructed through the iterative noncentral chi-square distribution method [12]. In addition, we applied a fixed-effect model when it was less than $50 \%$ and would have applied the random-effects model if it had been $50 \%$ or more. $p<0.05$ indicated a significant difference between the protein intake and control groups. The results are presented as mean \pm SD 
and $95 \%$ CIs. Forest plots were used to summarize results, and funnel plots were used to investigate publication bias.

\section{Results}

\subsection{Baseline Characteristics of the Selected Studies}

We searched 739 articles in total and sorted them with EndNote $X 7^{\circledR}$. A total of 225 duplicates were excluded. We removed 461 studies for different reasons (reviews, metaanalyses, animal or cell experiments, and no relationship). Fifty-three papers were left for further assessment after reading the titles and abstracts. After reading the full articles, it was observed that 41 studies did not satisfy the selection criteria. Finally, 12 articles were included in the systematic review and meta-analysis [13-24]. A of 872 participants (440 and 432 participants in the intervention group and the controls) that met the eligibility criteria were included in this review (Table 2). Sample sizes ranged from 32 to 146.

Table 2. Characteristics of the randomized controlled trials included in this systematic review and meta-analysis.

\begin{tabular}{|c|c|c|c|c|c|}
\hline $\begin{array}{l}\text { Author, } \\
\text { Year }\end{array}$ & Participants & Intervention & Comparison & Duration & Results \\
\hline $\begin{array}{l}\text { Tieland, } \\
2012\end{array}$ & 65 frail elderly & $15 \mathrm{~g}$ protein, bid & Placebo & $24 \mathrm{wk}$ & $\begin{array}{c}\text { HG-, chair rise-, } \\
4 \text { m gait speed-, SPPB } \uparrow\end{array}$ \\
\hline $\begin{array}{l}\text { Chale, } \\
2013\end{array}$ & $\begin{array}{l}80 \text { adult aged } \\
70-85 \text { years }\end{array}$ & $40 \mathrm{~g}$ whey protein/day & $\begin{array}{l}\text { Isocaloric } \\
\text { control }\end{array}$ & $6 \mathrm{mo}$ & SPPB- \\
\hline $\begin{array}{l}\text { Stout, } \\
2013\end{array}$ & $\begin{array}{c}43 \text { male or female } \\
\text { aged } \geq 65 \text { years } \\
36 \text { male or female } \\
\text { aged } \geq 65 \text { years } \\
\text { with resistance exercise }\end{array}$ & $\begin{array}{l}3 \text { g HMB/day } \\
3 \text { g HMB/day }\end{array}$ & Placebo & $24 \mathrm{wk}$ & $\begin{array}{l}\mathrm{HG}- \\
\mathrm{HG} \uparrow\end{array}$ \\
\hline $\begin{array}{l}\text { Berton, } \\
2015\end{array}$ & 65 healthy women & 1.5 g HMB/day & Control & $8 w k$ & $\begin{array}{c}\text { SMI-, } \mathrm{HG}^{-}, \\
\text {chair stand-, } \\
\text { 4-m gait speed, SPPB } \uparrow\end{array}$ \\
\hline $\begin{array}{l}\text { Kemmler, } \\
2016\end{array}$ & $\begin{array}{c}50 \text { women aged } \\
\geq 70 \text { years with } \\
\text { sarcopenic obesity }\end{array}$ & $40 \mathrm{~g}$ protein/day & Control & $6 \mathrm{mo}$ & SMI-, HG- \\
\hline $\begin{array}{c}\text { Mori, } \\
2018\end{array}$ & $\begin{array}{l}50 \text { women aged } \\
65-80 \text { years }\end{array}$ & $22.3 \mathrm{~g}$ protein/day & Control & 24 wk & SMI-, HG- \\
\hline $\begin{array}{l}\text { Amasene, } \\
2019\end{array}$ & $\begin{array}{l}28 \text { participants } \\
\text { aged }>70 \text { years, }\end{array}$ & $20 \mathrm{~g}$ whey protein/day & Placebo & $12 \mathrm{wk}$ & SPPB- \\
\hline $\begin{array}{l}\text { Bjorkman, } \\
2019\end{array}$ & $\begin{array}{l}146 \text { older persons } \\
\text { (>74 years of age) } \\
\text { with sarcopenia }\end{array}$ & $\begin{array}{l}20 \mathrm{~g} \\
\text { protein, bid }\end{array}$ & Placebo & $12 \mathrm{mo}$ & SMI-, HG-, SPPB- \\
\hline $\begin{array}{l}\text { ten Haaf, } \\
2019\end{array}$ & $\begin{array}{l}114 \text { adults } \\
\text { aged } 67-73 \text { years }\end{array}$ & $\begin{array}{l}36.8 \mathrm{~g} \\
\text { milk protein }\end{array}$ & Placebo & $12 \mathrm{wk}$ & $\begin{array}{l}\text { HG-, chair stand-, } \\
4 \text { m gait speed-, }\end{array}$ \\
\hline $\begin{array}{l}\text { Nilsson, } \\
2020\end{array}$ & 32 male aged $\geq 65$ years & $24 \mathrm{~g}$ whey protein/day & Placebo & $12 \mathrm{wk}$ & $\begin{array}{l}\mathrm{SMI} \uparrow, \mathrm{HG} \uparrow, \text { chair rise--, } \\
4 \mathrm{~m} \text { gait speed } \uparrow, \mathrm{SPPB}-\end{array}$ \\
\hline $\begin{array}{l}\text { Rondanelli, } \\
\quad 2020\end{array}$ & $\begin{array}{c}127 \text { adults aged } \geq 65 \\
\text { years with sarcopenia }\end{array}$ & $\begin{array}{c}20 \text { g whey protein, } \\
\text { b.i.d. }\end{array}$ & Placebo & $8 w k$ & $\begin{array}{c}\mathrm{SMI}-, \mathrm{HG} \uparrow \text {, chair rise } \uparrow, \\
\mathrm{SPPB} \uparrow\end{array}$ \\
\hline $\begin{array}{l}\text { Yamamoto, } \\
2021\end{array}$ & $\begin{array}{l}36 \text { patients aged } 70-79 \\
\text { years with type } 2 \mathrm{DM}\end{array}$ & $3 \mathrm{~g}$ protein, b.i.d. & Control & $48 \mathrm{wk}$ & HG- \\
\hline
\end{tabular}




\subsection{Risk-of-Bias Assessment}

We assessed the risk of bias by the Cochrane Handbook for Systematic Reviews of Interventions in the selected studies [8]. The results are shown in Figure 2. One study [21] was classed "high risk" and six studies [13-15,17,19,24] classed "unclear" with selection bias for allocation concealment. For the performance bias, Berton (2015) [14] classed "high risk" and Yamamoto (2021) [24] classed "unclear." Three studies (Amasene, 2019; Berton, 2015; Mori, 2018) $[13,14,18]$ were assessed as "high risk" and two studies $[23,24]$ assessed as "unclear" with detection bias. For attrition bias, five studies (Amasene, 2019; Berton, 2015; Nilsson, 2020; Stout, 2013; Tieland, 2012) were judged "high risk" [13,14,19,21,23].

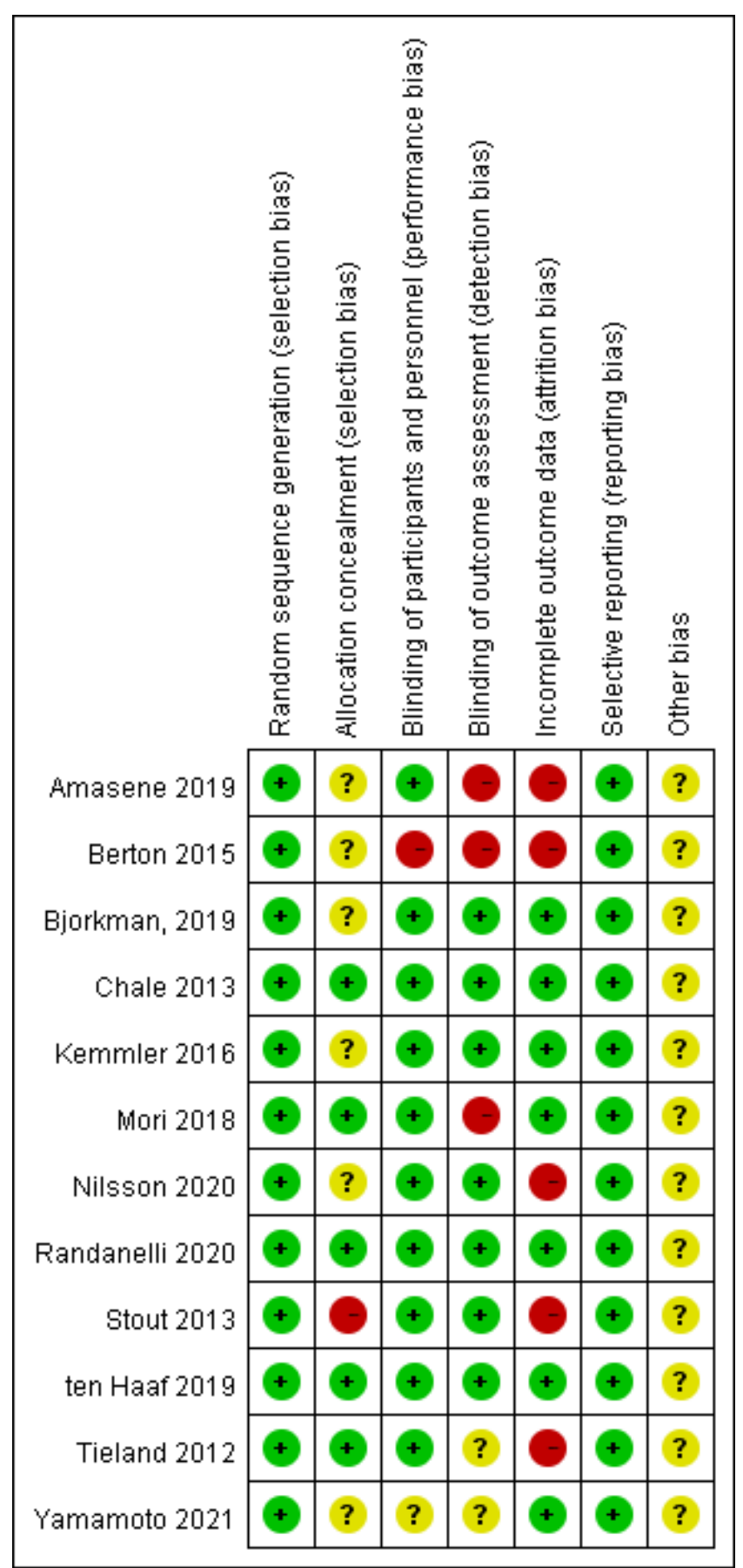

Figure 2. Risk-of-bias assessments for the selected studies. 


\subsection{Outcome Measures}

3.3.1. The Effects of Protein Intake on Muscle Mass and Strength

Six trials with 235 and 235 participants in the intervention and control groups, respectively, assessed the effect of protein intake on muscle mass with a focus on the skeletal muscle mass index $[14,15,17-20]$. With random-effects models, there were no significant changes in skeletal muscle mass by protein intake (mean difference $=0.01,95 \% \mathrm{CI}:-0.07$, 0.10 ). The $I^{2}$ value was $54 \%$, and the related $p$ value was 0.74 . The corresponding results are presented in Figure 3a. These data show that protein intake did not significantly affect skeletal muscle mass.

Ten RCTs with 383 and 381 participants in the intervention and control groups, respectively, assessed the effect of protein intake on muscle strength with a focus on hand grip strength $[14,15,17-24]$. With random-effects models, no difference in hand grip strength was observed in protein intake compared with control conditions (mean difference $=0.62$, $95 \%$ CI: $-0.37,1.60)$. The $I^{2}$ value was $93 \%$, and the related $p$ value was 0.22 . The corresponding results are presented in Figure $3 \mathrm{~b}$. These data show that protein intake did not significantly affect hand grip strength.

\subsubsection{The Effect of Protein Intake on Physical Performance}

\subsubsection{1. $\mathrm{m}$ Gait Speed}

There were four trials with 140 and 136 participants in the intervention and control groups, respectively $[14,19,22,23]$. With fixed-effects models, protein intake did not have significant changes in $4 \mathrm{~m}$ gait speed (mean difference $=-0.03,95 \% \mathrm{CI}:-0.06,0.00$ ). The $I^{2}$ value was $0 \%$, and the related $p$ value was 0.05 . The corresponding results are presented in Figure $3 c$. These data show that protein intake did not significantly affect $4 \mathrm{~m}$ gait speed.

\section{Chair Rise Test}

There were five trials with 204 and 199 participants in the intervention and control groups, respectively $[14,19,20,22,23]$. With random-effects models, there were no changes in the chair rise test (mean difference $=1.70,95 \% \mathrm{CI}:-1.54,4.93$ ). The $I^{2}$ value was $99 \%$, and the related $p$ value was 0.30 . The corresponding results are presented in Figure $3 \mathrm{~d}$. These data show that protein intake did not significantly affect the chair rise test.

\section{Short Physical Performance Battery (SPPB)}

There were seven trials with 276 and 267 participants in the intervention and control groups, respectively $[13-16,19,20,23]$. With random-effects models, there were no changes in SPPB (mean difference $=0.50,95 \%$ CI: $-0.25,1.25$ ). The $I^{2}$ value was $95 \%$, and the related $p$ value was 0.19 . The corresponding results are presented in Figure 3e. These data show that protein intake did not significantly affect SPPB. 
(a) Skeletal muscle mass index

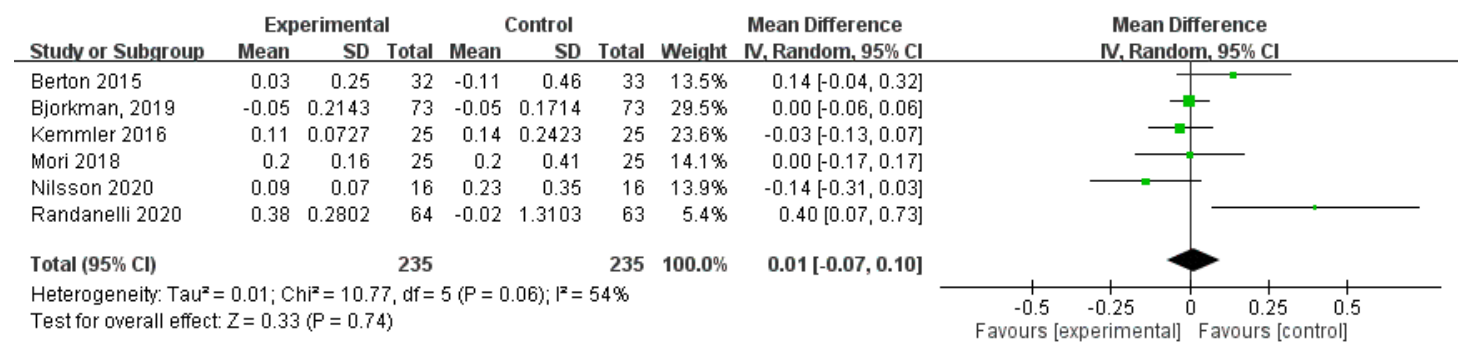

(b) Hand grip strength

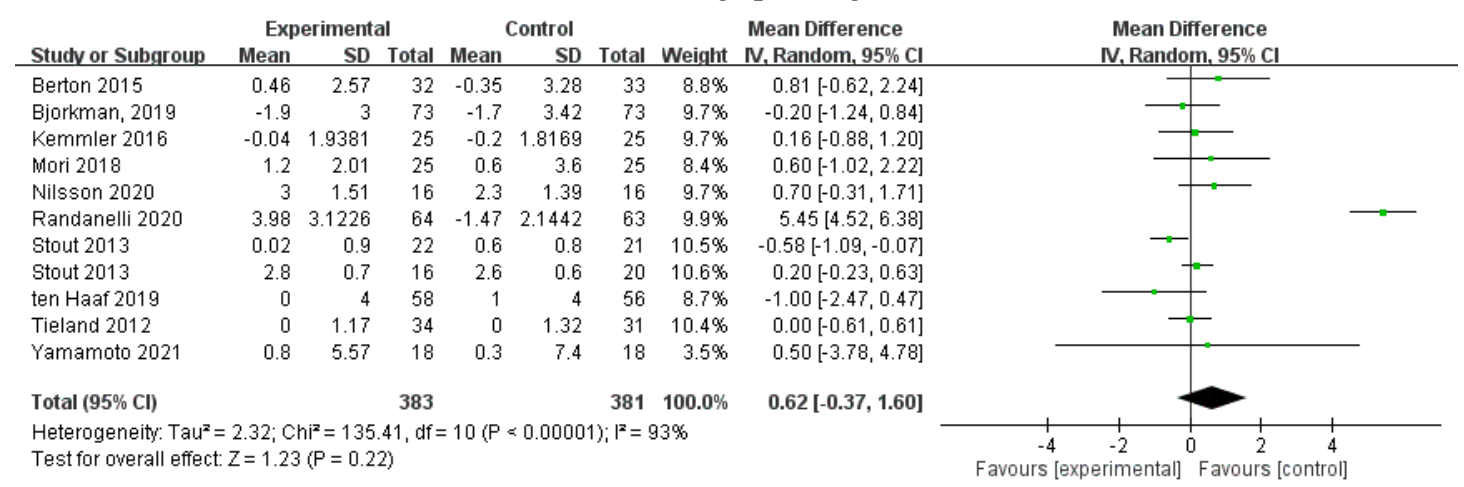

(c) 4 m gait speed

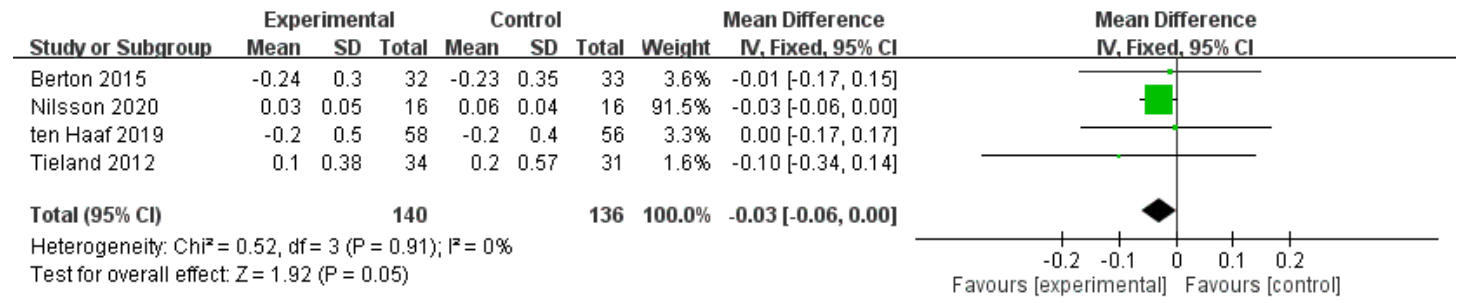

(d) Chair rise test

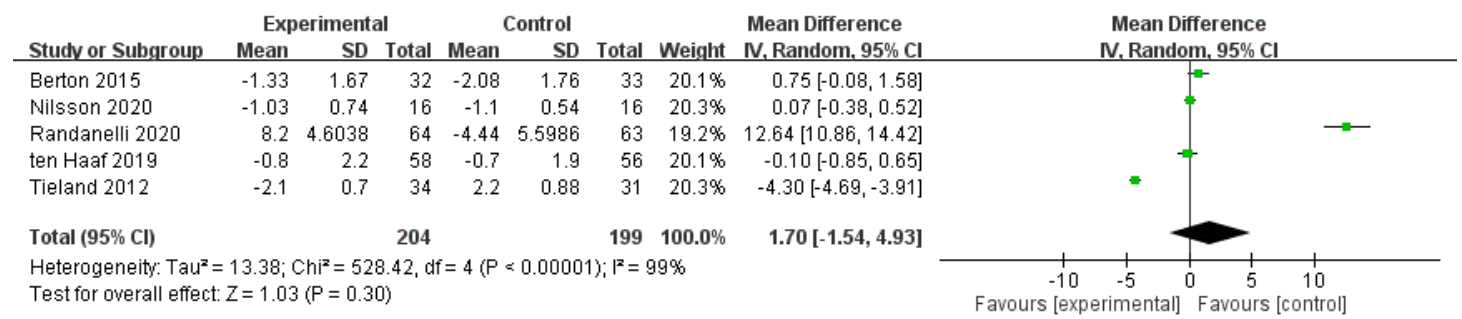

(e) SPPB

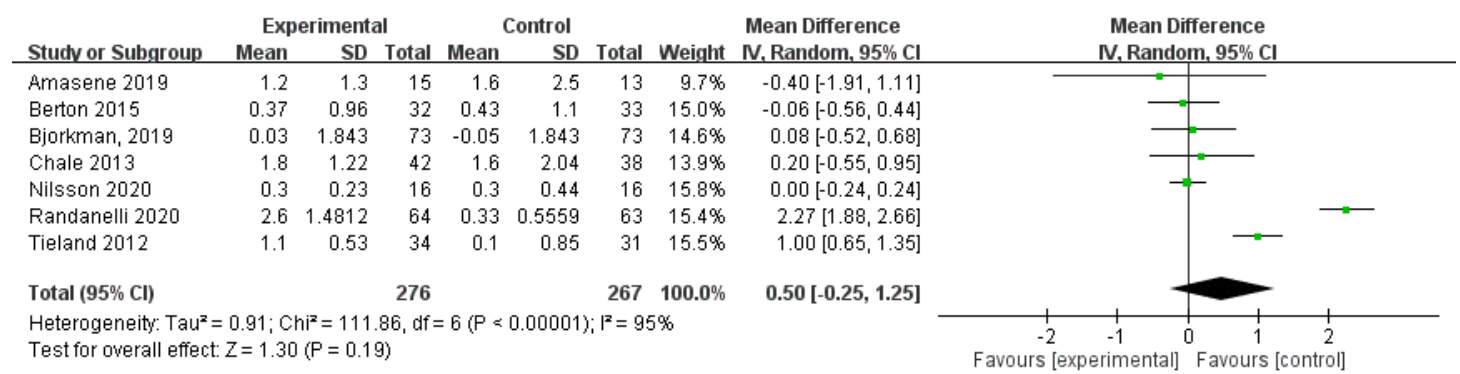

Figure 3. Forest plot of the effect of protein intake on (a) muscle mass: skeletal muscle mass index, (b) muscle strength: hand grip strength, physical performance: (c) 4 m gait speed, (d) chair rise test, and (e) short physical performance battery (SPPB) in randomized clinical trials. 


\subsection{Publication Bias}

Publication bias is defined as the failure to publish the results of a study depending on the direction and statistical significance of the study findings [8]. As Figure 4 shows, the funnel plot of $4 \mathrm{~m}$ gait speed (c) is symmetric, but the funnel plots of skeletal muscle mass index (a), hand grip strength (b), chair rise test (d), and SPPB (e) are asymmetric and present some publication bias.

(a)

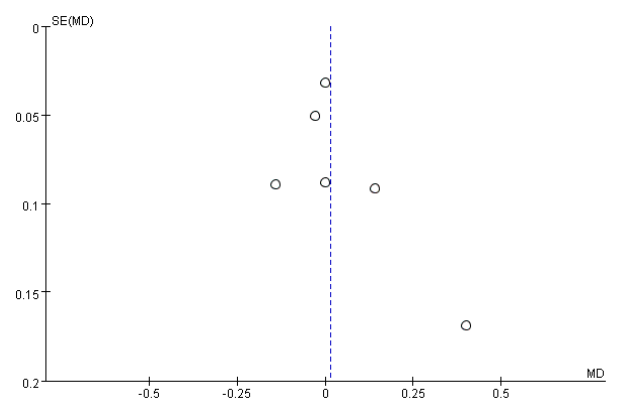

(c)

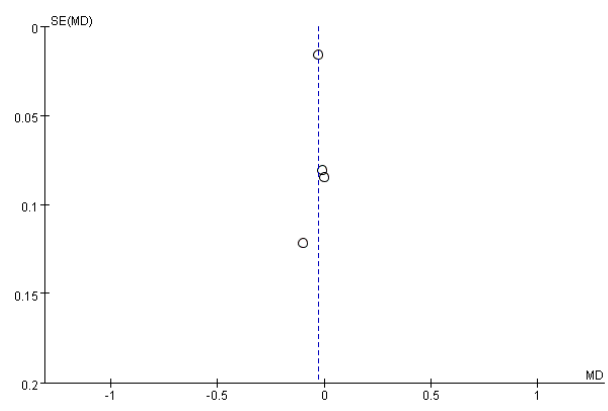

(b)

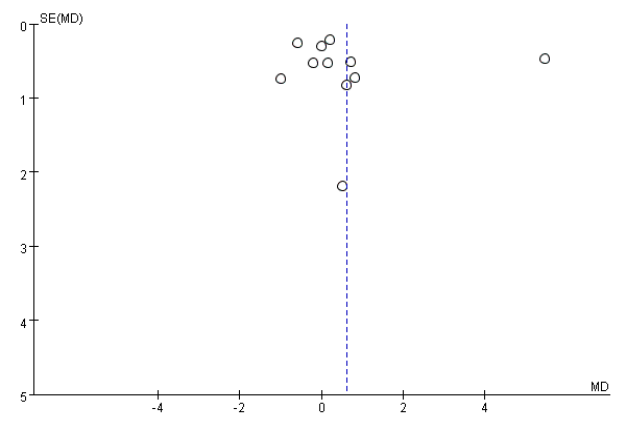

(d)

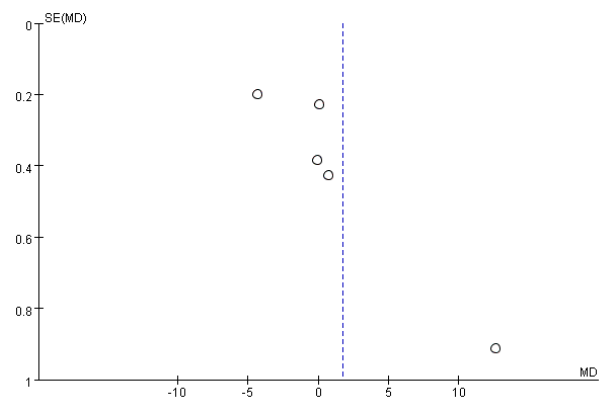

(e)

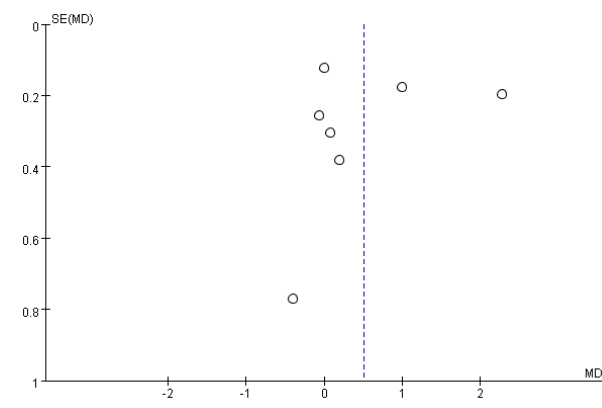

Figure 4. Funnel plot: (a) skeletal muscle mass index, (b) hand grip strength, (c) $4 \mathrm{~m}$ gait speed, (d) chair rise test, and (e) SPPB.

\section{Discussion}

\subsection{Clinical Implication}

The purpose of this meta-analysis was to know the effect of protein intake on the prevention and improvement of sarcopenia. The results of the study show that the protein intake had no significant effect on the physical performance- $4 \mathrm{~m}$ gait speed, chair rise test, SPPB, muscle mass—skeletal muscle mass index, and muscle strength—hand grip strength.

Of the reviewed trials included, only two had all the parameters of sarcopenia diagnosis, such as muscle mass, muscle strength, and physical function, which were updated by the Asian Working Group in 2019 [25]; we were unable to explore the effect of protein intake in preventing and treating the outcome of sarcopenia completely. Furthermore, we 
need more studies that include all the outcomes in connection with the Asian Working Group, which recommended the outcome for sarcopenia diagnosis.

Protein intake enhances muscle protein synthesis; the elderly need sufficient protein intake to prevent the risk of sarcopenia. Many people consume protein supplements habitually, without considering body weight and the total protein intake from meals. According to the Sarcopenia and Physical Frailty in Older People: Multi-component Treatment Strategies (SPRINTT) project, the average daily protein intake of at least $1.0-1.2 \mathrm{~g} / \mathrm{kg}$ body mass could prevent sarcopenia [26]. The safety and effectiveness concerning the consumption of $1.4 \mathrm{~g}$ of protein $/ \mathrm{kg}$ of body weight (or more) in the older population has been studied [27]. Dietary protein provides amino acids, which are necessary for the synthesis of muscle protein. However, it is not clear whether protein requirements need to be higher in the older population to keep nitrogen balance and to prevent loss of muscle mass and strength [28].

In addition, the components of protein used in the intervention groups of the included trials varied. Although well-planned diet regimens may have clinical effectiveness, or are possibly better than individual nutrient supplements in maintaining muscle mass and physical function in elderly adults, we need more RCTs for further subgroup analysis to assess whether various protein sources are a confounding factor and then to confirm that improvement is caused by specific proteins and effective dosage in the elderly population.

\subsection{Practical Applications}

It may be appropriate to assess the nutritional condition in elderly adults who are at risk of sarcopenia and frailty through investigations, body weight assessment, and selected blood compositions due to a sufficient nutritional profile that appears to help sustain muscle mass and preserve levels of physical function. From the clinical viewpoint, to prevent and improve sarcopenia, the strategy of protein supplements needs to consider body weight and protein intake from meals. The registered dietician will take a complete nutrition assessment, including anthropometry, biochemical data, clinical findings, and dietary recall to calculate the dosage of protein supplement needed in the elderly. The frequency of nutrition assessment in the elderly population is at least once a year; if there is a risk of malnutrition or nutrition problem, they need a reassessment three months later to ensure good nutrition condition.

\subsection{Methodological Considerations}

There were several limitations to this study. Firstly, the number of available RCTs was insufficient, so that the statistical power was low because of the small study sample size. Secondly, studies were included from only three databases (PubMed, Embase, and Cochrane Library), which calls into question the generalization of the findings and the strength of the conclusions. Thirdly, the forms and dosage of protein supplements were not consistent. Finally, the total dietary protein intake was not considered, on the basis of which it can be assessed whether the quantity of total protein intake is sufficient or not. We suggest a further perspective study to explore the effect of the quantity of total protein intake, including dietary intake from food and supplements such as protein powder and protein drink, on sarcopenia.

\section{Conclusions}

Protein supplementation has no significant effect on improving skeletal muscle mass index, hand grip strength, $4 \mathrm{~m}$ gait speed, chair rise test, and SPPB. This may be caused by the lack of clinical standards on the form or dosage of protein supplements. Therefore, a large population cohort study needs to be established in the future for further discussion.

Author Contributions: D.-Y.T. and T.-H.T. made a full assessment of all the data in the study and take responsibility for the integrity of the data and the accuracy of the analysis. D.-Y.T. and F.-M.K. contributed to data extraction and data analysis. D.-Y.T., S.-T.T., and T.-H.T. contributed to the interpretation and drafting of the manuscript. All authors have read and agreed to the published version of the manuscript. 
Funding: There were no sources of funding, whether financial or otherwise, for any of the authors (such as consultancies, employment, expert testimony, honoraria, speakers' bureaus, retainers, stock options or ownership).

Conflicts of Interest: The authors declare no conflict of interest.

\section{References}

1. Papadopoulou, S.K. Sarcopenia: A Contemporary Health Problem among Older Adult Populations. Nutrients 2020, $12,1293$. [CrossRef]

2. Santilli, V.; Bernetti, A.; Mangone, M.; Paoloni, M. Clinical definition of sarcopenia. Clin. Cases Miner. Bone Metab. 2014, 11, 177-180. [CrossRef] [PubMed]

3. Grimby, G.; Saltin, B. The ageing muscle. Clin. Physiol. 1983, 3, 209-218. [CrossRef]

4. von Haehling, S.; Morley, J.E.; Anker, S.D. An overview of sarcopenia: Facts and numbers on prevalence and clinical impact. J. Cachexia Sarcopenia Muscle 2010, 1, 129-133. [CrossRef]

5. Phair, R.D. Mechanistic modeling confronts the complexity of molecular cell biology. Mol. Biol. Cell 2014, 25, 3494-3496. [CrossRef] [PubMed]

6. Wells, J.L.; Dumbrell, A.C. Nutrition and aging: Assessment and treatment of compromised nutritional status in frail elderly patients. Clin. Interv. Aging 2006, 1, 67-79. [CrossRef] [PubMed]

7. Richter, M.; Baerlocher, K.; Bauer, J.M.; Elmadfa, I.; Heseker, H.; Leschik-Bonnet, E.; Stangl, G.; Volkert, D.; Stehle, P. On behalf of the German Nutrition Society (DGE). Revised Reference Values for the Intake of Protein. Ann. Nutr. Metab. 2019, 74, 242-250. [CrossRef]

8. Higgins, J.; Green, S. Cochrane Handbook for Systematic Reviews of Interventions Version 5.1.0; The Cochrane Collaboration: Oxford, UK, 2011.

9. Higgins, J.P.; Altman, D.G.; Gøtzsche, P.C.; Jüni, P.; Moher, D.; Oxman, A.D.; Savovic, J.; Schulz, K.F.; Weeks, L.; Sterne, J.A.; et al. The Cochrane Collaboration's tool for assessing risk of bias in randomised trials. BMJ 2011, 343, d5928. [CrossRef]

10. Review Manager (RevMan) [Computer Program]. Version 5.4.1. Copenhagen: The Nordic Cochrane Centre. The Cochrane Collaboration. 2020. Available online: https://training.cochrane.org/online-learning/core-software-cochrane-reviews/revman (accessed on 20 May 2021).

11. Higgins, J.P.; Thompson, S.G.; Deeks, J.J.; Altman, D.G. Measuring inconsistency in meta-analyses. BMJ 2003, 327, 557-560. [CrossRef] [PubMed]

12. Hedges, L.V.; Pigott, T.D. The power of statistical tests for moderators in meta-analysis. Psychol. Methods 2004, 9, 426-445. [CrossRef]

13. Amasene, M.; Besga, A.; Echeverria, I.; Urquiza, M.; Ruiz, J.R.; Rodriguez-Larrad, A.; Aldamiz, M.; Anaut, P.; Irazusta, J.; Labayen, I. Effects of Leucine-Enriched Whey Protein Supplementation on Physical Function in Post-Hospitalized Older Adults Participating in 12-Weeks of Resistance Training Program: A Randomized Controlled Trial. Nutrients 2019, 11, 2337. [CrossRef]

14. Berton, L.; Bano, G.; Carraro, S.; Veronese, N.; Pizzato, S.; Bolzetta, F.; De Rui, M.; Valmorbida, E.; De Ronch, I.; Perissinotto, E.; et al. Effect of Oral Beta-Hydroxy-Beta-Methylbutyrate (HMB) Supplementation on Physical Performance in Healthy Old Women Over 65 Years: An Open Label Randomized Controlled Trial. PLoS ONE 2015, 10, e0141757. [CrossRef]

15. Björkman, M.P.; Suominen, M.H.; Kautiainen, H.; Jyväkorpi, S.K.; Finne-Soveri, H.U.; Strandberg, T.E.; Pitkälä, K.H.; Tilvis, R.S. Effect of Protein Supplementation on Physical Performance in Older People with Sarcopenia-A Randomized Controlled Trial. J. Am. Med. Dir. Assoc. 2020, 21, 226-232.e1. [CrossRef]

16. Chalé, A.; Cloutier, G.J.; Hau, C.; Phillips, E.M.; Dallal, G.E.; Fielding, R.A. Efficacy of whey protein supplementation on resistance exercise-induced changes in lean mass, muscle strength, and physical function in mobility-limited older adults. J. Gerontol. A Biol. Sci. Med. Sci. 2013, 68, 682-690. [CrossRef] [PubMed]

17. Kemmler, W.; Teschler, M.; Weissenfels, A.; Bebenek, M.; von Stengel, S.; Kohl, M.; Freiberger, E.; Goisser, S.; Jakob, F.; Sieber, C.; et al. Whole-body electromyostimulation to fight sarcopenic obesity in community-dwelling older women at risk. Resultsof the randomized controlled FORMOsA-sarcopenic obesity study. Osteoporos. Int. 2016, 27, 3261-3270. [CrossRef]

18. Mori, H.; Tokuda, Y. Effect of whey protein supplementation after resistance exercise on the muscle mass and physical function of healthy older women: A randomized controlled trial. Geriatr. Gerontol. Int. 2018, 18, 1398-1404. [CrossRef] [PubMed]

19. Nilsson, M.I.; Mikhail, A.; Lan, L.; Carlo Di, A.; Hamilton, B.; Barnard, K.; Hettinga, B.P.; Hatcher, E.; Tarnopolsky., M.G.; Nederveen, J.P.; et al. A Five-Ingredient Nutritional Supplement and Home-Based Resistance Exercise Improve Lean Mass and Strength in Free-Living Elderly. Nutrients 2020, 12, 2391. [CrossRef]

20. Rondanelli, M.; Cereda, E.; Klersy, C.; Faliva, M.A. Improving rehabilitation in sarcopenia: A randomized-controlled trial utilizing a muscle-targeted food for special medical purposes. J. Cachexia Sarcopenia Muscle 2020, 11, 1535-1547. [CrossRef]

21. Stout, J.R.; Smith-Ryan, A.E.; Fukuda, D.H.; Kendall, K.L.; Moon, J.R.; Hoffman, J.R.; Wilson, J.M.; Oliver, J.S.; Mustad, V.A. Effect of calcium $\beta$-hydroxy- $\beta$-methylbutyrate (CaHMB) with and without resistance training in men and women $65+y$ rs: A randomized, double-blind pilot trial. Exp. Gerontol. 2013, 48, 1303-1310. [CrossRef] [PubMed]

22. Ten Haaf, D.S.M.; Eijsvogels, T.M.H.; Bongers, C.C.W.G.; Horstman, A.M.H.; Timmers, S.; de Groot, L.C.P.G.M.; Hopman, M.T.E. Protein supplementation improves lean body mass in physically active older adults: A randomized placebo-controlled trial. J. Cachexia Sarcopenia Muscle 2019, 10, 298-310. [CrossRef] 
23. Tieland, M.; van de Rest, O.; Dirks, M.L.; van der Zwaluw, N.; Mensink, M.; van Loon, L.J.; de Groot, L.C. Protein supplementation improves physical performance in frail elderly people: A randomized, double-blind, placebo-controlled trial. J. Am. Med. Dir. Assoc. 2012, 13, 720-726. [CrossRef] [PubMed]

24. Yamamoto, Y.; Nagai, Y.; Kawanabe, S.; Hishida, Y.; Hiraki, K.; Sone, M.; Tanaka, Y. Effects of resistance training using elastic bands on muscle strength with or without a leucine supplement for 48 weeks in elderly patients with type 2 diabetes. Endocr. $J$. 2021, 68, 291-298. [CrossRef]

25. Chen, L.K.; Woo, J.; Assantachai, P.; Auyeung, T.W.; Chou, M.Y.; Iijima, K.; Jang, H.C.; Kang, L.; Kim, M.; Kim, S.; et al. Asian working group for sarcopenia: 2019 consensus update on sarcopenia diagnosis and treatment. J. Am. Med. Dir. Assoc. 2020, 21, 300-307. [CrossRef] [PubMed]

26. Landi, F.; Cesari, M.; Calvani, R.; Cherubini, A.; Di Bari, M.; Bejuit, R.; Mshid, J.; Andrieu, S.; Sinclair, A.J.; Sieber, C.C.; et al. The "Sarcopenia and Physical fRailty IN older people: Multi-componenT Treatment strategies" (SPRINTT) randomized con-trolled trial: Design and methods. Aging Clin. Exp. Res. 2017, 29, 89-100. [CrossRef] [PubMed]

27. Naseeb, M.A.; Volpe, S.L. Protein and exercise in the prevention of sarcopenia and aging. Nutr. Res. 2017, 40, 1-20. [CrossRef] [PubMed]

28. Ganapathy, A.; Nieves, J.W. Nutrition and Sarcopenia-What Do We Know? Nutrients 2020, 12, 1755. [CrossRef] [PubMed] 